\title{
Primary Cutaneous B-Cell/T-Cell (Non- MF/SS) Lymphoma M0 TNM Finding v8
}

National Cancer Institute

\section{Source}

National Cancer Institute. Primary Cutaneous B-Cell/T-Cell (Non-MF/SS) Lymphoma MO

TNM Finding v8. NCI Thesaurus. Code C141374.

No evidence of extracutaneous non-lymph node disease. (from AJCC 8th Ed.) 